\title{
Integrating organizational learning with high-performance work system and entrepreneurial orientation: a moderated mediation framework
}

\author{
Chunling Zhu, Anqi Liu and Yangwen Wang
}

\author{
* Correspondence: wangyangwen@ \\ rmbs.ruc.edu.cn \\ Business School, Renmin University \\ of China, Rm 809B, Mingde Business \\ Building, 59 Zhongguancun Street, \\ Haidian District, Beijing 100872, \\ China
}

\begin{abstract}
This study proposes a moderated mediation model to investigate the relationship between organizational learning and firm performance. We argue that entrepreneurial orientation mediates the positive effect of organizational learning on firm performance. Furthermore, the relationship between organizational learning and entrepreneurial orientation is strengthened when firms employ a higher level of high-performance work system. Hypotheses are supported by data from 181 firms operating in the manufacturing and service industries in China. Statistical results further reveal that a high-performance work system has different moderating effects on exploitative learning and exploratory learning. This research extends our understanding of organizational learning theory, entrepreneurship and human resource management literature by cross-fertilizing constructs in these fields with empirical evidence.
\end{abstract}

Keywords: Organizational learning, Organizational performance, Entrepreneurial orientation, High-performance work system (HPWS), Exploitative learning, Exploratory learning

\section{Introduction}

In today's world of ever-increasing competition, organizational learning has been regarded as a core capability of effective firms (Bamiatzi et al. 2016) and a key element of corporate strategy (Schilling and Fang 2014). At a broader level, promoting organizational learning plays a key role in transforming and upgrading the national economy because organizational learning represents attempts to create knowledge assets as well as put forward practical methods to manage knowledge assets (North and Kumta 2018). Since learning is believed to be "the next source of competitive advantage" or "the only source of competitive advantage" (Fernández-Mesa and Alegre 2015) and the key to future success of a company (Kang et al. 2010), it is crucial for both scholars and practitioners to explore its significance in organizational development.

Existing studies have long revealed the positive effect organizational learning has on organizational performance (e.g., Chung et al. 2015; Popova-Nowak and Cseh 2015). However, the mechanism of how organizational learning improves

(c) The Author(s). 2019 Open Access This article is distributed under the terms of the Creative Commons Attribution 4.0 International License (http://creativecommons.org/licenses/by/4.0/), which permits unrestricted use, distribution, and reproduction in any medium, provided you give appropriate credit to the original author(s) and the source, provide a link to the Creative Commons license, and indicate if changes were made. 
organizational performance requires better theorization (e.g., Hakala 2011). Some scholars have argued that the relationship between organizational learning and performance may be indirect (e.g., Altinay et al. 2016). It is important to identify the mediating variables between these two factors in order to better promote the effects of organizational learning. Furthermore, there is an increasing emphasis on deploying internal operations to enhance the outcomes of firm-level resources and capabilities, such as organizational learning. Therefore, our aims in the current study are twofold. First, we investigate the underlying mechanism of the relationship between organizational learning and firm performance by identifying the mediator. Second, we look into organizations' internal operations to identify the moderator that boosts the effects of organizational learning.

Entrepreneurial orientation has been one of the most popular constructs in explaining firm performance in the ever-changing business environment in recent years (Covin and Slevin 1989; Lumpkin and Dess 2001). Scholars have long called for integration and cross-fertilization of the entrepreneurship and organizational learning literature in an entrepreneurial environment (Escribá-Esteve et al. 2008; Kreiser 2011). Entrepreneurial orientation has been theorized into a strategic resource which is embedded in tacit knowledge (Dess and Lumpkin 2005), and has even become regarded as a learning construct (Fernández-Mesa and Alegre 2015). With a strong learning capability, firms can form a solid knowledge base necessary for entrepreneurial activities (Chung et al. 2015), which further enhances organizational performance. Therefore, in a changing environment, we believe that entrepreneurial orientation acts as the bridge between organizational learning and firm performance.

Furthermore, we argue that high-performance work system (HPWS), a human resource management practice that has received a great deal of attention, interacts with organizational learning to produce synergetic effects on entrepreneurial orientation. HPWS is a management approach to improve business performance through systematic integration of a series of best human resource management practices (Wei and Lau 2010). However, the importance of HPWS has not been fully valued (Chen et al. 2016; $\mathrm{Li}$ et al. 2015). Successful implementation of organizational learning needs support from internal managerial approaches (Prieto and Revilla 2006). Through a systematic training process, building organizational routines and a flexible work design, HPWS helps create a learning atmosphere which encourages acquiring, integrating and sharing knowledge to facilitate organizational learning (Akgun et al. 2003; Wei and Lau 2010; Wright et al. 2001).

Using survey data from top executives in 181 Chinese firms in the manufacturing and service industries, we establish a moderated mediation framework proposing that organizational entrepreneurial orientation mediates the positive relationship between organizational learning and performance, in which HPWS moderates the first-stage mediation effect, and the overall theoretical model. Our theoretical model is shown in Fig.1. Integrating entrepreneurship literature and human resource literature, this study contributes to relevant theories in three aspects. First, the mediating role of entrepreneurial orientation in the relationship between organizational learning and performance reveals an influential map for organizational learning by integrating organizational learning with entrepreneurship 


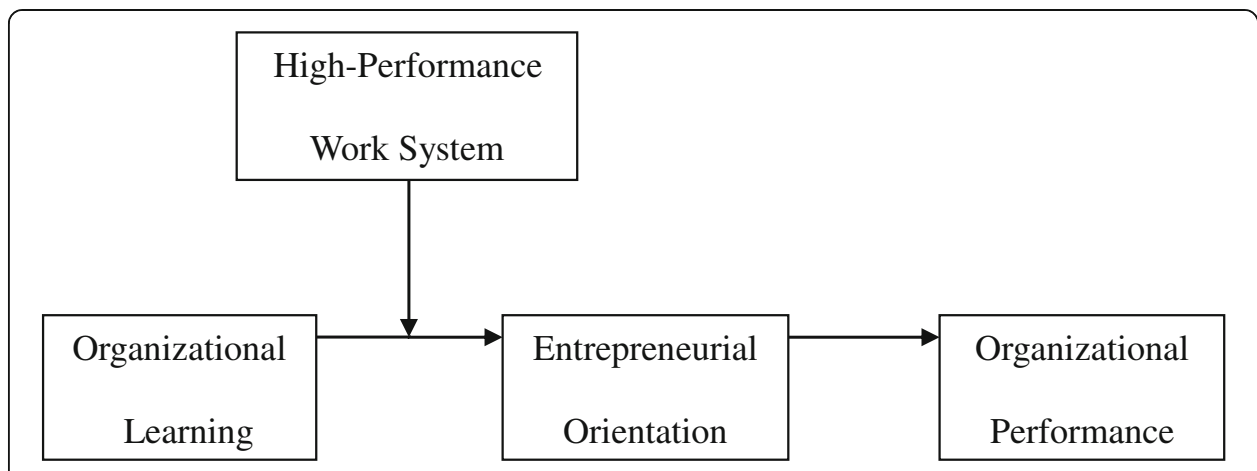

Fig. 1 Theoretical framework

literature, which responds to the call from previous studies (Kreiser 2011). Second, the boundary condition in the effect of organizational learning indicates the important interactive effect of human resource management and organizational learning in boosting firm performance. Finally, additional analyses further disclose different synergetic effects between exploitative learning, exploratory learning and the HPWS.

\section{Theory and hypotheses}

\section{Organizational learning and performance}

Organizational learning originates in organizational behaviors, systems and managerial practices, occurs through organizational routines and acts on information or knowledge and subsequently modifies potential organizational behaviors and performance (Dixon et al. 2007; Jerez-Gomez et al. 2005). Through the learning process, companies can expand the knowledge base, improve the ability to utilize information and develop effective strategies and structures to manage change in uncertain environments (Fernández-Mesa and Alegre 2015). However, regarding many aspects of organizational change, research in the field of organizational learning has always suffered from excessively broad conceptions and failed to converge into a coherent whole (Popper and Lipshitz 2000; Chung et al. 2015). One of the first widely accepted definitions states that organizational learning is a process in which an organization continues to find its own errors during operation and then corrects them by reorganizing the structure (Argyris and Schon 1978). Following the work of Sanzo et al. (2012), in the present study, we define organizational learning as a dynamic process through which members create, acquire and integrate knowledge based on gathered information in order to develop the resources and capabilities of the organization.

Organizational learning theory suggests that the effect of organizational learning takes places in two forms: exploitation and exploration (Chung et al. 2015). Exploitation learning succeeds the prior knowledge of the organization, develops operational capabilities and improves existing organizational routines. Exploration learning can develop entirely new routines and enhance strategic flexibility and creativity (Dixon et al. 2007). In short, through utilizing, institutionalizing and improving the exploration and transitional efficiency of knowledge, organizations internalize knowledge, establishing a 
valuable resource. Just as Argyris and Schon (1978) suggest, knowledge is deeply embedded in organizational memory or institutionalized into systems, structures, strategies, routines and practices. It is vital to highlight that although learning is rooted in individual members, organizational learning is not simply the cumulative result of individual knowledge (Lipshitz and Popper 2000; Popova-Nowak and Cseh 2015). Organizations create cohesive systems and establish organizational routines which allow members to acquire, interpret and transmit information (Fiol and Lyles 1985; Levitt and March 2003; Popper and Lipshitz 2000). These similar but not identical processes enable us to analyze learning at organizational level.

As knowledge is a fundamental strategic asset that companies can process and use to build their competitive advantage (Chung et al. 2015), organizational learning has been recognized as a substantial element enabling companies to obtain competitive advantages and improve organizational performance (North and Kumta 2018). Organizational learning can enlarge the organizational knowledge base and improve capabilities and skills, which stimulates innovative ideas and behaviors (Noruzy et al. 2013). Employing heightened skills and stronger abilities allows companies to identify and utilize market opportunities; that is to say, take actions earlier and more efficiently (Eisenhardt 1989; Li et al. 2009). Although a variety of literature has revealed particular aspects of organizational learning, a more systematic understanding of its effect mechanism is needed. Therefore, we use the positive relationship between organizational learning and firm performance as our baseline model to further develop the moderated mediation model in this paper.

\section{The mediating role of entrepreneurial orientation}

Entrepreneurial orientation represents a strategic choice of an organization-a general or lasting direction of thought, inclination, or interest toward entrepreneurship-which focuses on opportunity recognition and resource exploration as well as guiding decision-making and behaviors (Altinay et al. 2016; Lumpkin and Dess 2001). Despite the many varied dimensions of entrepreneurial orientation developed by scholars, the original three-dimension model, which consists of innovativeness, proactiveness and risk-taking, is still highly recognized in the academic world (Naldi et al. 2007). Innovativeness refers to the propensity for a firm to promote novelty and investment in R\&D (Lumpkin and Dess 1996). Demonstrating a forward-looking propensity, proactiveness taps a firm's anticipating and acting abilities for future needs (Miller and Friesen 1978). Risk-taking propensity refers to the willingness of a firm to make large and risky resource commitments (Miller and Friesen 1978). With the potential cost of failures, entrepreneurial firms engage in risk-taking behaviors by seeking opportunities in the market (Lumpkin and Dess 1996). Following the work of Clercq et al. (2015), in this study, we adopt the composite dimension approach to explore the relationship between organizational learning and the overall level of entrepreneurial orientation.

Entrepreneurial orientation acts as a mediator between organizational learning and firm performance (Altinay et al. 2016). In the meditation process, entrepreneurial orientation transforms the knowledge generated through organizational learning into innovative and opportunity-seizing behavior, and finally contributes to 
firm performance. Entrepreneurial orientation helps complete the process of knowledge generation, knowledge utilization, and value realization.

First, organizational learning generates knowledge to realize entrepreneurial orientation. In an entrepreneurial environment, firms with a learning mechanism can enlarge the organizational knowledge base and increase a firm's ability to acquire, utilize and spread organizational knowledge (Wolff et al. 2015; Wang 2008). This increased knowledge base facilitates a firm's innovativeness, proactiveness and risk-taking propensity to expand market and launch new products (Dada and Fogg 2016; Eisenhardt 1989; Noruzy et al. 2013). Regarding innovativeness, increased knowledge boosts creative thoughts and behaviors to solve work-related problems with novel solutions, leading to a more creative and flexible way of working (Altinay et al. 2016; Floyd and Lane 2000; Noruzy et al. 2013). Regarding proactiveness, with increased knowledge, firms have a greater chance to identify market opportunities and are more likely to form new insights into breakthrough innovations (Weinzimmer and Esken 2017). Companies with higher learning capabilities are able to act on opportunities more rapidly and confidently (Eisenhardt 1989). Regarding risk-taking, increased knowledge improves a firm's capability to understand environmental change and identify business trends, and thus reduces uncertainty. Moreover, this capability provides the firm with more confidence in adapting to environmental changes and uncertainty (Dada and Fogg 2016). Therefore, companies with a high level of organizational knowledge are more likely to take high-risk-and-high-return adventures (Fernández-Mesa and Alegre 2015). To sum up, organizational learning influences a firm's inclination to engage in innovative, proactive and risk-taking activities. By enhancing the ability to innovate, seek opportunities and take advanced actions, organizational learning can lead to continuous and proactive entrepreneurial engagements (Bamiatzi et al. 2016).

With respect to the second aspect, utilizing knowledge, entrepreneurial orientation can improve firm performance. Firms with a higher level of entrepreneurial orientation show greater innovation tendency, risk-taking willingness and proactiveness. These dimensions improve the capabilities of the company, such as improved reactions to the external environment, capitalizing on market opportunities and adaption to dynamics. More specifically, entrepreneurial orientation enhances a firm's dynamic capabilities to seek for opportunities and invest valuable resources in promising products (Dada and Fogg 2016). From a resource-based view, these capabilities are valuable and inimitable; thus, companies can build a sustained competitive advantage. Firms with entrepreneurial orientation are more likely to establish relationships with suppliers, customers, and other stakeholders (Messersmith and Wales 2013). These networks can provide firms with critical resources and information, which contributes to further development. Furthermore, firms with an entrepreneurial orientation can better utilize resources. Entrepreneurial orientation is a type of managerial approach which can improve implementation capacity (Fernández-Mesa and Alegre 2015). Firms use entrepreneurial orientation as a mechanism to transform the advantage provided by the environment into above-average performance levels (Rosenbusch et al. 2013). As these firms constantly update their management system and the mode of manufacture, break market boundaries, and launch new products and services in order to grasp market orientation ahead of competitors, organizational performance can be consequently improved. 
In conclusion, entrepreneurial orientation acts as a mediator between organizational learning and firm performance. Therefore, we hypothesize:

Hypothesis 1: In an entrepreneurial environment, organizational entrepreneurial orientation mediates the positive relationship between organizational learning and organizational performance.

\section{High-performance work system as the moderator}

The outcomes of organizational learning can be affected by many factors, such as leadership, the external environment, and human resource management (North and Kumta 2018). Strategic human resource management may play an essential role in influencing organizational effectiveness (Tsao et al. 2009). As a focal topic in the field of strategic human resource management, high-performance work system (HPWS), which is also known as high-performance work practices, high-commitment work system, or high-involvement work system, can generally be defined as a set of interactive human resource management practices, mainly including scientific recruiting procedures, extensive training, authorization, participation in decision-making, performance-based compensation, and information sharing (Chow et al. 2013; Posthuma et al. 2013; Wei and Lau 2010). Being consistent with corporate strategy, HPWS emphasizes systematic integration of HR practices rather than particular activities (Shin and Konrad 2017). We therefore regard HPWS as a comprehensive construct of human resource practices, in accord with previous studies (Macky and Boxall 2007).

Unique human resource practices and the skills of staff are embedded in the organizational structure and routines, making a company more flexible and adaptable to the external environment (Becker and Huselid 2006). As a managerial approach, HPWS invests in training, builds strong structure, allows work design and encourages creative information sharing practices (Wright et al. 2001). In this way, it encourages employees to absorb, transfer and implement knowledge and improve staff abilities (Huselid 1995). Therefore, HPWS paves the way for organizational learning (Wei and Lau 2010) and ultimately promotes innovative activities.

Furthermore, through investing in employees, HPWS helps an organization develop a committed workforce. Through enhancing fairness, increasing trust and providing intrinsic rewards, HPWS creates a more reliable atmosphere, and stimulates stronger attachment to the organization and a greater dedication to work (Chuang et al. 2016). Employees are thus inspired to focus on the process of knowledge acquisition and up-skilling, and therefore more incentivized to utilize existing knowledge and create new knowledge (Akgun et al. 2003; Tsao et al. 2009). Perceiving organizational support, employees can exploit new knowledge to confidently take actions ahead of competitors and engage in high-risk ventures in order to improve organizational performance, rather than feeling concerned about potential negative outcomes and organizational penalties (Cohen and Sproull 1996; Floyd and Wooldridge 1999). By producing synergistic effects, HPWS thus improves organizational competency (Chahal et al. 2016). 
In addition to seizing entrepreneurial opportunities and implementing entrepreneurial practices, companies need to establish internal procedures and systems to promote knowledge development (Cohen and Sproull 1996; Floyd and Wooldridge 1999). In short, HPWS can work interactively with organizational learning to further improve organizational entrepreneurial activities. When firms implement HPWS, the promotional effect of organizational learning on organizational entrepreneurial orientation is more significant. Based on this theoretical analysis, we have formulated the following hypothesis:

Hypothesis 2: HPWS moderates the relationship between organizational learning and entrepreneurial orientation, such that this relationship is strengthened when HPWS is high.

\section{A moderated mediation effect}

Based on the above analysis, we hope to integrate the single mediation effect and the moderation effect and therefore propose a moderated mediation model. Organizational learning can promote organizational entrepreneurial orientation through enlarging the knowledge base and improving organizational abilities (Altinay et al. 2016; Lumpkin and Lichtenstein 2005; Noruzy et al. 2013). Entrepreneurial orientation can further help the organization recognize opportunities, utilize current resources and establish close relationships with stakeholders, consequently promoting organizational performance (Dada and Fogg 2016; Messersmith and Wales 2013; Rosenbusch et al. 2013). This mediation effect can be moderated by HPWS. A high level of HPWS can interact with organizational learning and enhance entrepreneurial orientation, which consequently benefits organizational performance. Thus, we propose the following hypothesis:

Hypothesis 3: HPWS moderates the first-stage indirect relationship between organizational learning and organizational performance, such that this indirect effect is stronger at a higher rather than lower level of HPWS.

\section{Methods}

\section{Sample and data collection}

The research team was granted access to a variety of companies from an executive training program at a university. Companies were randomly selected. All survey respondents were either founders or professional managers involved in strategic decision-making in their respective firms. Therefore they are appropriate candidates to assess organizational level constructs.

Before the formal distribution of questionnaires, researchers explained the purpose of the survey to all respondents, guaranteed the anonymity and confidentiality of the survey to prevent consistency motif and social desirability (Ambos et al. 2013), and emphasized the importance of authentic answers. There were two formal distribution channels: an online survey website and on site delivery. All together 450 questionnaires were administered, of which 221 were returned. After 
eliminating 32 incomplete questionnaires, and eight questionnaires whose total score are either too high or too low, the final effective number of surveys is 181 . The total effective rate is $40.22 \%$.

To test possible non-response bias (Armstrong and Overton 1977), we conducted $t$-tests and found no statistically significant differences between respondents and non-respondents on major firm attributes such as firm size, type and operation years, which suggests the survey approach is valid. Further, the total sample was divided into early-response and late-response subgroups (Armstrong and Overton 1977), as well as responses collected online and from the on-site groups. $T$-tests on model variables suggest insignificant differences between these two groups.

We have summarized the information of the effective sample firms, including industries, firm size, firm age, whether the firm is publicly listed or not, and managerial level of respondents. Of the final sample, $61.33 \%$ of the firms belong to the manufacturing industry, $38.67 \%$ are from the service industry; $27.62 \%$ are publicly listed. $17.32 \%$ of the firms have fewer than 300 employees; $60.18 \%$ have employees numbering between 300 and 1000; $22.5 \%$ have more than 1000 employees. $23.20 \%$ of the firms have been in operation for fewer than 5 years; 25.41\% between 6 and 10 years; 30.94\% between 11 and 20 years; $20.44 \%$ for more than 20 years. $18.23 \%$ of the enterprises are state-owned or state-controlled; $70.17 \%$ are private-owned or private-controlled; $11.6 \%$ are foreign-owned or foreign-controlled. The average age of interviewees is 39.51, and the average tenure in their management position is 6 years. Of all the respondents, $45.79 \%$ are founders or senior managers; $54.21 \%$ are middle managers. $42.36 \%$ of the respondents are female, and $57.64 \%$ are male.

\section{Common method variance}

To alleviate potential common method bias, we adopted several procedures to minimize the variance. First, for each company, we invited two top executives form decision-making teams to answer the questionnaire. We then matched their answers regarding organizational learning and organizational performance, to eliminate self-report bias to a large extent. Second, before sending formal questionnaires, we randomly selected managers to have face-to-face interviews in order to verify that each question could be clearly understood. The research team carefully explained each item to the interviewees and answered any questions. According to their feedback, we slightly adjusted any confusing, irrelevant or repetitive questions to ensure the clarity and simplicity of the questionnaire. We then mixed the order of items so respondents could not predict possible relationships between constructs (Ambos et al. 2013). Finally, we reverse-coded some items, in order to prevent respondents being able to figure out the intention of the questionnaire. As the constructions of this research contained interactional effects, the possibility that respondents would surmise the relationships between variables is relatively small (Aiken et al. 1991).

Following the above steps, Harman's single factor analysis was performed to test the common method variance concern (El Akremi et al. 2010). Results show that the first factor contributes $31 \%$ of the covariances, indicating the common method bias does not seriously affect the conclusion of the research. 


\section{Measurement of constructs}

We measured all of the multi-item variables using a Likert five-point scale, in which 1 represents completely inconsistent and 5 means full compliance. The scales of the questionnaire were all translated from the original English version to Chinese by experts, and then translated back to English to ensure there were no translation errors or vagueness. Specific questionnaire items that measure the variables are presented in Appendix.

\section{Independent variable}

Organizational learning refers to the process by which members gather, integrate, create and spread information and knowledge (Sanzo et al. 2012). Specifically, exploitative learning improves current organizational routines and integrates intra-organizational knowledge; exploratory learning develops new routines and tries to explore opportunities outside the company (Dixon et al. 2007). In this study we used the scale developed by Atuahene-Gima and Murray (2007), which included the exploration and exploitation processes of organizational learning. Sample items include "We emphasized the use of knowledge related to our existing project experiences." "Our aim was to collect new information that forced us to learn new things in the product development project."

\section{Mediator and moderator}

We used a three-dimensional measurement developed by Covin and Slevin (1989) to measure entrepreneurial orientation. The dimensions included innovation, early action and risk taking. The three-dimensional measurement tables are widely used in empirical research because of their comprehensiveness and accuracy. The scale has been tested in many different cultural contexts, which shows its usefulness in different cultural situations (Chadwick et al. 2008; Kreiser et al. 2002). Therefore, this study selected the Govin-Slein three-dimensional measurement table as the measurement scale. The scale consists of 9 items and the original test reliability is 0.84 . Sample items are as follows: "Changes in product or service lines have usually been quite dramatic." "In general, the top managers of my firm have a strong proclivity for high-risk projects (with chances of very high returns)."

The measurement of HPWS has not been agreed upon among scholars. Yet most of the scales cover common points such as extensive training, fair pay assessment and promotion mechanism, higher level of employee commitment, etc. Su (2010) have proposed an 8-dimension scale to assess HPWS, which includes 28 items for which the original test reliability is 0.864 . Eliminating three inappropriate items with low factor loading, this study included 25 items. Sample items include: "There is a standard training process in our company." "Employers pay attention to candidates' recognition of enterprise core values when recruiting." "Staff enjoy the opportunity to transfer jobs inside the company" etc.

\section{Dependent variable}

Scholars have developed various scales to measure this concept from different perspectives (e.g., Cheng and Zhao 2011; Dyer and Reeves 1995; Ruekert et al. 1985). 
Since there is no agreement on this concept, it is difficult to measure the absolute organizational performance objectively. Furthermore, the respondents of this research are mainly founders or professional managers of private companies which are not publicly listed on the stock exchange. Therefore, it is difficult for researchers to find financial data on enterprise performance from an open information source.

Additionally, since most private companies in this study are preparing for listing, they are reluctant to disclose absolute sales or profit data. To eliminate the self-report bias to the largest extent, we asked them to compare the current-year financial data with those of the previous year. Each reported the growth of sales, growth of market valuation, growth of net profits and growth of assets. We then matched the answers from the same company. Studies have shown that there is a strong correlation between absolute performance and relative performance (Covin and Slevin 1989; Delaney and Huselid 1996; Dess and Robinson 1984). Therefore, we used a longitudinal comparison of organizational performance in the main regression and also used later comparison with competitors in a robustness check to corroborate the validation.

\section{Control variables}

Consistent with previous studies, this research controls variables such as firm size, ownership type, operation time, industry type and whether the firm is listed or not (Chow et al. 2013; Greve 2003; Guthrie 2001; Song et al. 2005). Prior research suggested that firm size may influence the level of innovation and performance (Song et al. 2005), so we considered the natural logarithm of the number of employees to represent firm size. Ownership is another characteristic that may influence human resource practices and organizational learning issues (Chow et al. 2013). Thus, we categorized ownership types as state-owned, private-owned and foreign-owned. Firm age is relevant to managerial experience and competency (Huergo and Jaumandreu 2004) and thus may affect the organizational performance. Therefore, we included firm age by counting the operational years of the companies. As firms in different industries may also differ in the intensity and frequency of R\&D activities (Greve 2003), we introduced a dummy variable to represent industry type.

Controlling variables are coded according to the following rules: Firm size is the natural logarithm of employee number. Firms from the manufacturing industry are coded 0 and firms from the service industry are coded 1 . Listed firms are coded 1, or else 2. Firms whose operation time is less than 5 years are coded 1, between 5 and 10 years are coded 2, between 11 and 20 years are coded 3, and more than 20 years are coded 4. Ownership types are coded into two dummy variables and controlled for in the hypotheses testing.

\section{Results}

Construct reliability

Reliability mainly reflects the stability and consistency of the results when the questionnaire items are repeatedly measured. In empirical research, the most 
common analysis method for the Likert scale is Cronbach's $\alpha$ analysis. The Cronbach's $\alpha$ of the core constructs organizational learning, HPWS and organizational performance are $0.923,0.947$ and 0.905 respectively, indicating strong reliability. The Cronbach's $\alpha$ of entrepreneurial orientation is 0.808 , which also reflects high reliability. The composite reliability of organizational learning, entrepreneurial orientation, organizational performance and HPWS are 0.936, 0.877, 0.934 and 0.952, which demonstrates high internal equity of the variables.

\section{Construct validity}

Validity reflects the degree that the scale can accurately reflect the content that is measured. At present, the commonly used method for validity analysis of scale is factor analysis. In this study, we first used the KMO method and Barlett's sphericity test to judge whether the item is suitable for factor analysis. Further we used exploratory factor analysis to test the construct validity of the scale. The results are showed in Table 1.

Table 1 shows that the KMO values of organizational learning and HPWS are higher than 0.9 and the KMO values of entrepreneurial orientation and organizational performance are higher than 0.8. The effect of Barlett's sphericity test is significant. This indicates that the validity analysis of the scale meets the requirement of factor analysis. The cumulative variance indicates strong construct validity of the scale.

In order to confirm constructs discriminant validity, we adopted AMOS 22.0 to conduct confirmatory factor analysis. Results are shown in Table 2. We compared the four-factor model with the three-factor model, two-factor model and single-factor model. Typically, if $\chi^{2} / d f<5$, IFI $>0.9$, CFI $>0.9$, RMSEA $<0.08$, the variables have high discriminant validity. Results show that the four-factor model has the highest model fit $\left(\chi^{2}(48)=113.262\right.$, IFI $=0.962$, CFI $=0.962$, RMSEA $=$ 0.087).

\section{Descriptive statistics and correlations}

In order to have an overall understanding of the sample, we first carried out descriptive statistical and correlation analysis of the sample data. Table 3 shows the mean value, standard deviation and correlation among variables. According to the correlation coefficient matrix, there is significant positive correlation between the main variables, which provides a good foundation for further analysis.

Table 1 Validity analysis of the scale

\begin{tabular}{llll}
\hline Variable & KMO value & Barlett's sphericity test & Cumulative variance \\
\hline OL & 0.909 & 0.000 & $59.348 \%$ \\
EO & 0.802 & 0.000 & $61.625 \%$ \\
HPWS & 0.918 & 0.000 & $66.579 \%$ \\
OP & 0.820 & 0.000 & $77.852 \%$ \\
\hline
\end{tabular}

Notes. HPWS: high-performance work system, EO: entrepreneurial orientation, OL: organizational learning, OP: organizational performance 
Table 2 Confirmatory factor analysis

\begin{tabular}{lllllll}
\hline Model & $x^{2}$ & $d f$ & $x^{2} / d f$ & IFI & CFI & RMSEA \\
\hline Four-factor model: HPWS, EO, OL, OP & 113.262 & 48 & 2.360 & 0.962 & 0.962 & 0.087 \\
Three-factor model: HPWS, EO+ OP, OL & 355.834 & 51 & 6.977 & 0.824 & 0.821 & 0.182 \\
Three-factor model: HPWS, EO+ OL, OP & 289.052 & 51 & 5.668 & 0.862 & 0.860 & 0.161 \\
Three-factor model: HPWS+EO, OL, OP & 310.003 & 51 & 6.078 & 0.850 & 0.848 & 0.168 \\
Two-factor model: HPWS+OL, EO + OP & 610.356 & 53 & 11.516 & 0.678 & 0.673 & 0.242 \\
Single-factor model: HPWS+OL + EO + OP & 833.364 & 54 & 15.433 & 0.549 & 0.542 & 0.283
\end{tabular}

Notes. HPWS high-performance work system, $E O$ entrepreneurial orientation, $O L$ organizational learning, $O P$ organizational performance, IFI incremental fit index, CFI comparative fit index, RMSEA root-mean-square error of approximation

\section{Hypothesis testing}

Before regression analyses, we mean-centered organizational learning, HPWS, organizational performance and entrepreneurial orientation to ensure there are no potential multi-collinear issues while testing moderating hypotheses (Aiken et al. 1991). Subsequent regression analyses suggest all variance inflation factor (VIF) values are lower than 10 (e.g., 1.75), which is the common cutoff value (Neter et al. 1996).

In order to test the moderated mediation model, we adopted multiple methods. First we employed the traditional method proposed by Baron and Kenny (1986) to test the causal relationships. Second we used the bootstrapping method recommended by Preacher and Hayes (2008) to test the moderated mediation effect.

According to Baron and Kenny (1986), there are usually four steps to test the mediating effects. First, the independent variable is significantly related to the dependent variable. Second, the independent variable is significantly related to the mediating variable. Third, the mediating variable significantly affects the dependent variable. Fourth, when adding the mediating variable to the main effect, the correlation between the independent variable and the dependent variable drops significantly.

Results of the mediation effect are displayed in Table 4. Model 1 and Model 5 include all control variables. Model 2 represents the first step of the mediation effect. The relationship between organizational learning and performance is significant $(\beta=0.289, p<0.001)$. Model 6 illustrates the effect of organizational learning on organizational entrepreneurial orientation, which is positively significant $(\beta=0.412, p<0.001)$. Model 3 represents the third step of the mediation effect $(\beta=0.379, p<0.001)$. Model 4 indicates the fourth step of the mediation effect. After adding entrepreneurial orientation as an independent variable, the relationship between organizational learning and performance is significantly decreased $(\beta=0.167$, n.s.). Meanwhile, the relationship between entrepreneurial orientation and organizational performance is positive and significant $(\beta=0.294$, $p<0.001$ ). All of the four steps are satisfied, supporting Hypothesis 1.

Consistent with the recent research trend to test mediation effects and to overcome the shortcomings of the multistep method (MacKinnon et al. 2004), we further conducted the Sobel test (Sobel, 1982) and bootstrapping method (Preacher and Hayes 2004). The SPSS process plug-in contains both a normal theory approach (the Sobel test) and a bootstrap method. Results are shown in Table 5. The Sobel test suggests the indirect effect is significant $(z=2.81, p<0.05)$. The bootstrap method confirms the mediation effect, in which the $95 \%$ confidence interval of the indirect effect does not 


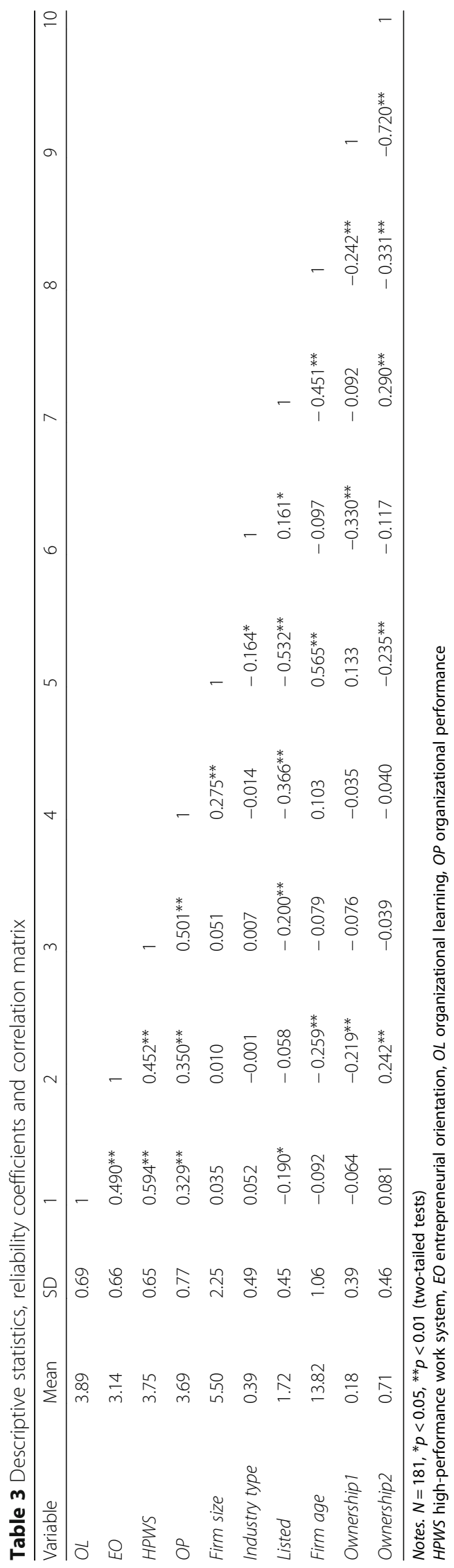


Table 4 Results of mediating and moderating effects (Hypotheses 1\&2)

\begin{tabular}{|c|c|c|c|c|c|c|c|c|}
\hline \multirow[t]{2}{*}{ DV } & \multicolumn{4}{|l|}{$\mathrm{OP}$} & \multicolumn{4}{|l|}{ EO } \\
\hline & Model 1 & Model 2 & Model 3 & Model 4 & Model 5 & Model 6 & Model 7 & Model 8 \\
\hline Constant & $4.553^{* * *}$ & $3.151^{* * *}$ & $3.133^{* * *}$ & $2.637^{* * *}$ & $3.746^{* * *}$ & $1.748^{* * *}$ & $1.151^{*}$ & $1.193^{* *}$ \\
\hline Firm size & $0.065^{*}$ & $0.062^{*}$ & 0.046 & 0.048 & 0.050 & 0.046 & 0.043 & $0.050^{*}$ \\
\hline Industry & 0.134 & 0.103 & 0.102 & 0.092 & 0.084 & 0.035 & 0.024 & 0.070 \\
\hline Listed & $-0.582^{* * * *}$ & $-0.437^{*}$ & $-0.476^{* *}$ & $-0.415^{* *}$ & $-0.279^{*}$ & -0.073 & -0.034 & 0.003 \\
\hline Duration & -0.096 & -0.054 & -0.009 & -0.004 & $-0.228^{* * *}$ & $-0.171^{* * *}$ & $-0.143^{* *}$ & $-0.163^{* *}$ \\
\hline Ownership1 & -0.197 & -0.213 & -0.141 & -0.164 & -0.147 & -0.167 & -0.077 & -0.147 \\
\hline Ownership2 & -0.003 & -0.061 & -0.091 & -0.104 & 0.232 & 0.148 & 0.247 & 0.152 \\
\hline OL & & $0.289^{* * *}$ & & 0.167 & & $0.412^{* * *}$ & $0.276^{* * *}$ & $0.284^{* * *}$ \\
\hline$E O$ & & & $0.379^{* * *}$ & $0.294^{* *}$ & & & & \\
\hline HPWS & & & & & & & $0.248^{* *}$ & $0.213^{* *}$ \\
\hline OLXHPWS & & & & & & & & $0.145^{* *}$ \\
\hline$R^{2}$ & 0.163 & 0.223 & 0.251 & 0.265 & 0.167 & 0.336 & 0.369 & 0.397 \\
\hline$\Delta R^{2}$ & - & 0.060 & 0.088 & 0.042 & - & 0.169 & 0.202 & 0.028 \\
\hline F & $5.620^{* * *}$ & $7.014^{* * *}$ & $8.252^{* * *}$ & $7.680^{* * *}$ & $5.781^{* * *}$ & $12.348^{* * *}$ & $12.331^{* * *}$ & $12.948^{* * *}$ \\
\hline$\Delta F$ & - & 1.394 & 2.632 & 0.666 & - & 6.567 & 6.550 & 0.617 \\
\hline Average VIF & 1.82 & 1.75 & 1.77 & 1.77 & 1.82 & 1.75 & 1.83 & 1.80 \\
\hline
\end{tabular}

Notes. ${ }^{*} p<0.05,{ }^{* *} p<0.01,{ }^{* * *} p<0.001$ (two-tailed tests)

$H P W S$ high-performance work system, $E O$ entrepreneurial orientation, $O L$ organizational learning, $O P$ organizational performance

contain zero $(0.05,0.22)$. In this way, the mediation effect of entrepreneurial orientation receives support.

\section{Moderation effect}

The test of moderating effect usually consists of two steps. The first is to introduce the independent and moderating variables into the model; then, add the interaction effect. Model 8 in Table 4 shows the positive interaction effect of organizational learning and HPWS $(\beta=0.145, p<0.05)$, providing support for Hypothesis 2 .

\section{Moderated mediation effect}

In order to integrate the overall effects of the mediating and moderating variables, we used the bootstrapping method to test the indirect relationship between organizational learning and organizational performance. Table 6 shows the conditional effect of organizational learning on organizational performance when HPWS is one standard deviation below ( $-1 \mathrm{SD})$, equal to, and one standard deviation above the mean value. When the level of HPWS is low, the confidence interval contains zero, suggesting the indirect effect of organizational learning is not significant. When the level of HPWS is mean and high, the indirect effects are all significant. Furthermore, the indirect effect is stronger at higher rather than lower level of HPWS, since the coefficient changes from 0.0453 to 0.1409 . Therefore, consistent with Hypothesis 3, the moderated mediation framework is supported. The moderating effect plot of HPWS is shown in Fig. 2. 
Table 5 Results of mediation effect using Sobel test and bootstrapping method (Hypothesis 1)

\begin{tabular}{|c|c|c|c|c|c|c|}
\hline & Effect & SE & BootLLC195\% ${ }^{a}$ & BootULC195\% ${ }^{a}$ & $z$ & $p$ \\
\hline & \multicolumn{6}{|c|}{ Indirect effect and significance using normal distribution } \\
\hline \multirow[t]{2}{*}{ Sobel } & 0.1213 & 0.0432 & - & - & 2.8050 & 0.0050 \\
\hline & \multicolumn{6}{|c|}{ Bootstrap results for indirect effect } \\
\hline Bootstrap & 0.1213 & 0.0432 & 0.0472 & 0.2174 & - & - \\
\hline
\end{tabular}

Notes. Unstandardized regression coefficients are reported. Results are based on 5000 bootstrap samples. ${ }^{a} 95 \%$ confidence intervals presented

\section{Robustness check}

In order to check the robustness of our results, we further measured organizational performance by asking respondents to compare their performance with that of the two main competitors of the focal company. We synthesized the mature scales developed by Dyer and Reeves (1995) and Cheng and Zhao (2011). The final scale contains three dimensions with 14 items, including financial performance, innovation performance and human resource performance. Sample items are as follows: "Compared to two main competitors, our company has a larger market share." "Compared to two main competitors, the skills of the employees in the company are promoted quickly." "Compared to two main competitors, our company develops new products quickly." Empirical results also confirm our hypotheses.

\section{Further analyses}

Following the empirical analyses above, we further distinguished the two dimensions of organizational learning, namely exploratory learning and exploitative learning, and tested their relationship with organizational entrepreneurial orientation and organizational performance. Results are interesting. Although the mediation effect and the moderation effect are confirmed by both exploratory and exploitative learning, the results of the moderated mediation model are different.

As Table 7 suggests, the total index for both moderated mediation models is significant. However, when HPWS is one standard deviation below the average value, the indirect effect of exploitative learning on organizational performance is not significant, which means a low level of HPWS cannot moderate the exploitative learning-entrepreneurial orientation-organizational performance effect. However, no matter what the level of HPWS is, the indirect effect of exploratory learning on organizational performance is significant. For firms with a high level of HPWS,

Table 6 Conditional indirect effects of organizational learning on organizational performance at values of HPWS (Hypothesis 3)

\begin{tabular}{llllll}
\hline & & \multicolumn{4}{l}{ Conditional indirect effects of organizational learning } \\
\cline { 3 - 6 } & HPWS & Effect & SE & BootLLC195\% ${ }^{\mathrm{a}}$ & BootULC195\% ${ }^{\mathrm{a}}$ \\
\hline EO & $-0.6541(-1 \mathrm{SD})$ & 0.0453 & 0.0274 & 0.0031 & 0.1177 \\
EO & O(Mean) & 0.0931 & 0.0320 & 0.0418 & 0.1706 \\
EO & 0.6541 (Mean) & 0.1409 & 0.0502 & 0.0589 & 0.2625 \\
& & Index of moderated mediation & & \\
EO & 0.0730 & 0.0377 & 0.0131 & 0.1656 \\
\hline
\end{tabular}

Notes. Results are based on 5000 bootstrap samples. Cl : confidence interval, EO: entrepreneurial orientation, HPWS: highperformance work system. ${ }^{\mathrm{a}} 95 \%$ confidence intervals presented 


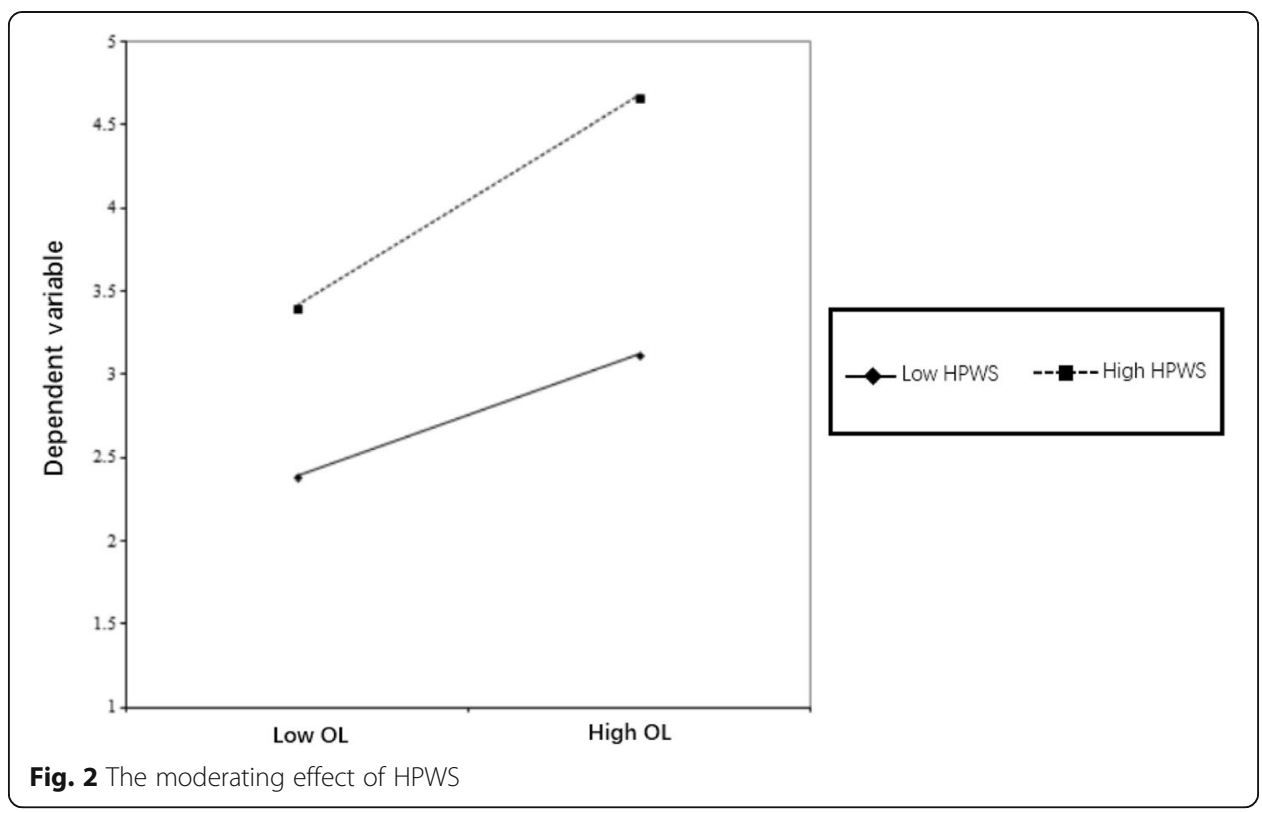

organizational learning can produce an even stronger positive influence on organizational performance through the mediating role of entrepreneurial orientation.

\section{Discussion}

Prior research has shown that there is a positive relationship between entrepreneurial orientation and organizational performance (Dada and Fogg 2016; Rauch et al. 2009; Walter et al. 2006). However, Altinay et al. (2016) have suggested that the cause-and-effect relationship between organizational learning and business performance is not straightforward and cannot be clearly defined because the mechanism of organizational learning may be too complex. The current study establishes a moderated mediation framework between organizational learning and organizational performance. Data from 181 companies support the mediating role of entrepreneurial orientation between organizational learning and firm performance, and the moderating role of HPWS to the effect of organizational learning on entrepreneurial orientation. The results indicate that within the context of the current changing business environment, there is an increasing necessity for firms to utilize entrepreneurial orientation in order to make the most out of the knowledge generated from learning process. It is also important to integrate firm resources and capabilities, such as organizational learning capability, with internal managerial operations, such as HPWS, to synthesize the effect of knowledge.

We further distinguish the two dimensions of organizational learning, namely exploratory learning and exploitative learning, and find that when HPWS is one standard deviation below the average value, the indirect effect of exploitative learning on organizational performance becomes insignificant. While the indirect effect of exploratory learning on organizational performance is significant despite of any level of HPWS, the results indicate that the indirect effect of exploitative learning on organizational performance is more affected by HPWS than exploratory learning. The reason behind these findings may be that exploitative learning is more closely related to the internal learning process while exploratory involves a more external learning process. HPWS 
Table 7 Conditional indirect effects of exploitative and exploratory learning on organizational performance at values of HPWS

\begin{tabular}{|c|c|c|c|c|c|}
\hline & HPWS & Effect & Standard error & BootLLC195\% ${ }^{\mathrm{a}}$ & BootULC195\% ${ }^{\mathrm{a}}$ \\
\hline \multicolumn{6}{|c|}{ Conditional indirect effects of exploitative learning } \\
\hline$E O$ & $-0.6579(-1 S D)$ & 0.0097 & 0.0306 & -0.0530 & 0.0711 \\
\hline$E O$ & 0 (Mean) & 0.0594 & 0.0320 & 0.0079 & 0.1370 \\
\hline$E O$ & 0.6579 (Mean) & 0.1091 & 0.0473 & 0.0358 & 0.2279 \\
\hline \multicolumn{6}{|c|}{ Index of moderated mediation } \\
\hline$E O$ & & 0.0755 & 0.0360 & 0.0173 & 0.1614 \\
\hline \multicolumn{6}{|c|}{ Conditional indirect effects of exploratory learning } \\
\hline$E O$ & $-0.6579(-1 S D)$ & 0.0543 & 0.0263 & 0.0149 & 0.1257 \\
\hline$E O$ & 0 (Mean) & 0.0989 & 0.0317 & 0.0450 & 0.1720 \\
\hline$E O$ & 0.6579 (Mean) & 0.1435 & 0.0500 & 0.0609 & 0.2636 \\
\hline \multicolumn{6}{|c|}{ Index of moderated mediation } \\
\hline$E O$ & & 0.0678 & 0.0369 & 0.0111 & 0.1632 \\
\hline
\end{tabular}

Notes. Results are based on 5000 bootstrap samples. Cl: confidence interval, EO: entrepreneurial orientation, HPWS: highperformance work system. ${ }^{\mathrm{a}} 95 \%$ confidence intervals presented

has been recognized as one potential means through which organizations can stimulate effective knowledge behaviors and develop the depth and content of their knowledge stocks (Chuang et al. 2016). Therefore, inner organizational human resource practices may interact with exploitative learning to a larger extent.

Prior studies have also pointed out that under certain circumstances, a high level of entrepreneurial orientation can have a negative effect on firm performance (Tang et al. 2008). This relationship exists when there is a lack of institutional support and organizational formalization to support the high level of entrepreneurial orientation. However, in the current study, with the high level of institutional support for entrepreneurship in China (Atuahene-Gima and Murray 2007), firms with a high level of entrepreneurial orientation do not suffer from this kind of disadvantage. However, researchers and practitioners should still be aware of this type of situation and the generalizability of the findings in the current study to countries with different institutional environments.

\section{Theoretical contributions}

This study makes three key contributions to existing theory and research. The first is related to organizational learning theory. This study explores the effect mechanism of organizational learning by answering the call to cross-integrate the organizational learning and entrepreneurship literature (Escribá-Esteve et al. 2008; Kreiser 2011; Zahra et al. 1999).

Following previous studies, which suggest that the success of entrepreneurial activities is inextricably linked to organizational learning ability (Altinay et al. 2016), this study argues that organizational learning can facilitate organizational entrepreneurial orientation. Dealing with the uncertainty of the external environment is the common starting point of organizational learning and entrepreneurial orientation. In fact, anyone who wants to achieve entrepreneurial goals must accumulate knowledge. Firms with strong learning capabilities can more efficiently explore, accumulate and spread 
knowledge, and thus encourage innovative behaviors, identify opportunities and take proactive actions (Eisenhardt 1989; Jerez-Gomez et al. 2005; Wang 2008), in order to enhance the level of corporate entrepreneurial orientation.

Therefore, to some extent, the process of entrepreneurship is also the process of recollection, management and utilization of knowledge. Moreover, we extend organizational learning literature by introducing HPWS as a moderating variable. The combination of internal managerial practices and organizational learning can promote organizational entrepreneurial orientation and consequently benefit organizational performance. Exploring the boundary conditions offers us deeper insights into the effect mechanism of organizational learning.

Second, under the current period of economic transition and public entrepreneurship, there is profound importance to study the relationship between entrepreneurial orientation and organizational performance. Our research suggests that entrepreneurial orientation can promote organizational performance by improving organizational capabilities, building close relationships with stakeholders and better utilizing resources, supporting the positive view of the entrepreneurial orientation (EO)-performance relationship (Dada and Fogg 2016; Rauch et al. 2009).

This study answers the call to combine entrepreneurial and strategic management perspectives in order to develop sustained competitive advantages (Escribá-Esteve et al. 2008; Hakala 2011). Our findings provide new ideas to the recent extension of the EO-performance research stream considering the effect of organizational learning and human resource management (Rauch et al. 2009; Wang 2008). Contrary to the findings of Wang (2008) and Covin et al. (2006), we conclude that the EO-performance relationship is not mediated by organizational learning. Instead, the relationship between organizational learning and organizational performance is mediated by entrepreneurial orientation, confirming the indirect relationship and incremental effect between organizational learning and performance (Altinay et al. 2016). The mediation effect of entrepreneurial orientation helps us open the "black box" of the relationship between organizational learning and performance, responding to the call to theorize the mechanism of the relationship of the organizational learning-performance relationship (Hakala 2011). Also, revealing the causal relationship between organizational learning and entrepreneurial orientation helps us find another valuable antecedent of entrepreneurial orientation (Zahra et al. 1999).

Third, this study finds that HPWS plays a positively moderating role between organizational learning and organizational entrepreneurial orientation. Further, HPWS can moderate the mediation effect of entrepreneurial orientation in the organizational learning-performance relationship. These findings unravel the importance of human resource practices compared to technical issues, which is generally overlooked in Asian contexts (Chen et al. 2016; Li et al. 2015).

HPWS improves staff knowledge and skills through strict recruitment and extensive training, thus strengthening the effect of organizational learning (Wei and Lau 2010; Wright et al. 2001). Furthermore, firms that use HPWS can stimulate the learning enthusiasm and organizational commitment of staff (Akgun et al. 2003; Tsao et al. 2009). Therefore, employees can more efficiently excavate, share, spread and utilize knowledge, so that the effect of organizational learning is more significant. The revelation of 
the interaction effect is in line with previous studies (Cohen and Sproull 1996; Floyd and Wooldridge 1999; Prieto and Revilla 2006) but the moderated mediation framework gives us a more synthesized view of these constructs.

Further analyses distinguishing exploitative learning and exploratory learning suggest the different interaction effect between different forms of organizational learning and human resource practices. Since exploitative learning mainly improves existing organization routines (Dixon et al. 2007), it can better interact with intra-organizational human resource management. Because exploratory learning involves exploring and establishing new routines, it is therefore less affected by human resource practices.

\section{Implications for managerial practice}

This research offers several implications for practice. This study firstly attaches importance to human resource management, which is usually disregarded when compared to technical improvements (Chen et al. 2016; Li et al. 2015). Our research suggests that HPWS can interact with organizational learning and generate synergetic effects to improve organizational performance. Therefore, managers should establish systematic human resource practices in order to formulate competitive advantages and surpass companies' rivals.

Second, our study reveals the significance of innovation and entrepreneurship in the dynamic contexts of emerging markets. Enterprises should cultivate their staff's entrepreneurial orientation and maintain enthusiasm for innovation so as to enhance the enterprise's level of innovation, the judgment and control ability of the dynamic market, and risk-taking ability, thus remaining competitive in a fierce market.

The third implication is that the integrated framework suggests that managers combine entrepreneurial practices, human resource practices and organizational learning policies in order to obtain competitive advantages.

\section{Limitations and future research directions}

Despite the efforts we have made in this research, there exist several limitations that could be addressed in the future research. First, the data of this study are cross-sectional. Future research can introduce panel data or experimental methods to further explore the causal relationships among the variables. Second, in this study we regard the economic development of different regions in China as homogenous. Some scholars have argued that sub-national economy may be heterogeneous, which therefore may affect enterprises' performance (Chan et al. 2010; York et al. 2018). Future research could test the generalization of our theoretical model in sub-national regions. Third, all variables in this research are in unitary dimension. As stated in previous sections, there are subsets of entrepreneurial orientation and HPWS. Future research could explore the respective relationship of each dimension with organizational learning and performance.

Acknowledgements

Not applicable.

Funding

Supported by the Fundamental Research Funds for the Central Universities, and the Research Funds of Renmin

University of China, 15XNF021. The Research Fund was used on collecting data and other related research materials. 


\section{Appendix}

Table $\mathbf{8}$ Constructs Measurement Items

\begin{tabular}{lll}
\hline Constructs & Items & Sources \\
\hline Organizational & $\begin{array}{l}\text { 1 Our aim was to search for information to refine common } \\
\text { learning }\end{array}$ & Atuahene-Gima and \\
& Methods and ideas in solving problems in the project. & Murray 2007
\end{tabular}

2 Our aim was to search for ideas and information that we can implement well to ensure productivity rather than those ideas that could lead to implementation mistakes in the project and in the marketplace.

3 We searched for the usual and generally proven methods and solutions to product development problems.

4 We used information acquisition methods (e.g., survey of current customers and competitors) that helped us understand and update the firm's current project and market experiences.

5 We emphasized the use of knowledge related to our existing project experience.

6 In the information search, we focused on acquiring knowledge of project strategies that involved experimentation and high market risks.

7 We preferred to collect information with no identifiable strategic market needs to ensure experimentation in the project.

8 Our aim was to acquire knowledge to develop a project that led us into new areas of learning such as new markets and technological areas.

9 We collected novel information and ideas that went beyond our current market and technological experiences.

10 Our aim was to collect new information that forced us to learn new things in the product development project.

Entrepreneurial orientation
1 In general, the top managers of my firm favor a strong emphasis on R\&D, technological leadership, and innovations.

2 In the past three years, my firm has marketed very many new lines of products or services.

3 In the past three years, changes in product or service lines have usually been quite dramatic.

4 In dealing with its competitors, my firm typically initiates actions which competitors then respond to.

5 In dealing with its competitors, my firm is very seldom the first business to introduce new products/services, administrative techniques, operating technologies, etc.

6 In dealing with its competitors, my firm typically adopts a very competitive, 'undo-the-competitor' posture.

7 In general, the top managers of my firm have a strong proclivity for high-risk projects (with chances of very high returns).

8 In general, the top managers of my firm believe that owing to the nature of the environment, bold, wide-ranging acts are necessary to achieve the firm's objectives.

9 When confronted with decision-making situations involving uncertainty, my firm typically adopts a bold, aggressive posture in order to maximize the probability of exploiting potential opportunities.

High-performance work system
1 There is standard training process in our company (corporate culture, management skills/professional skills, etc).

2 My firm invests more time and money in training than its competitors.

3 My firm has a standardized training process.

4 My firm resolutely punishes employees who violate the rules. 
Table 8 Constructs Measurement Items (Continued)

\begin{tabular}{|c|c|c|}
\hline Constructs & Items & Sources \\
\hline & 5 My firm has stricter discipline than its competitors. & \\
\hline & $\begin{array}{l}6 \text { All personnel in my firm can be awarded or punished } \\
\text { according to their performance. }\end{array}$ & \\
\hline & 7 Important positions in my firm are appointed by competition. & \\
\hline & $\begin{array}{l}8 \text { Employees can understand the production and financial } \\
\text { information of the firm in a timely manner. }\end{array}$ & \\
\hline & $\begin{array}{l}9 \text { Employees are able to keep abreast of the goals and progress } \\
\text { of the firm. }\end{array}$ & \\
\hline & $\begin{array}{l}10 \text { Employers pay attention to candidates' recognition of } \\
\text { enterprise core values when recruiting. }\end{array}$ & \\
\hline & $\begin{array}{l}11 \text { Compared with skills, my firm pays more attention to the } \\
\text { basic quality of candidates in recruitment. }\end{array}$ & \\
\hline & $\begin{array}{l}12 \text { My firm has a strict selection process (written examination, } \\
\text { interview, etc). }\end{array}$ & \\
\hline & $\begin{array}{l}13 \text { My firm selects excellent employees from a large number of } \\
\text { candidates. }\end{array}$ & \\
\hline & $\begin{array}{l}14 \mathrm{My} \text { firm has designed specific and clear assessment indicators } \\
\text { for all employees. }\end{array}$ & \\
\hline & $\begin{array}{l}15 \text { My firm implements rewards and punishments strictly based } \\
\text { on evaluation results. }\end{array}$ & \\
\hline & 16 The income of employees is linked to their evaluation results. & \\
\hline & $\begin{array}{l}17 \mathrm{My} \text { firm is willing to adopt short-term incentive remuneration, } \\
\text { such as performance bonuses. }\end{array}$ & \\
\hline & 18 My firm provides preferential treatment to key talents. & \\
\hline & $\begin{array}{l}19 \text { The overall salary level of my firm is competitive in the } \\
\text { market. }\end{array}$ & \\
\hline & 20 My firm has a perfect career development plan for employees. & \\
\hline & 21 My firm has perfect internal promotion channels. & \\
\hline & $\begin{array}{l}22 \text { Staff enjoy the opportunity to transfer jobs inside the } \\
\text { company. }\end{array}$ & \\
\hline & 23 My firm has a perfect staff recommendation system. & \\
\hline & 24 My firm encourages employees to participate in management. & \\
\hline & $\begin{array}{l}25 \text { My firm pays attention to the attitudes and opinions of } \\
\text { employees. }\end{array}$ & \\
\hline \multirow{4}{*}{$\begin{array}{l}\text { Organizational } \\
\text { performance }\end{array}$} & Compared to last year, the growth of sales this year is... & \multirow{4}{*}{$\begin{array}{l}\text { Delaney and Huselid } \\
\text { 1996; Bae and Lawler } \\
2000\end{array}$} \\
\hline & Compared to last year, the growth of market valuation is... & \\
\hline & Compared to last year, the growth of net profits is ... & \\
\hline & Compared to last year, the growth of assets is... & \\
\hline
\end{tabular}

Availability of data and materials

Please contact author for data requests.

\section{Authors' contributions}

$\mathrm{CZ}$ was in charge of the writing, the data collection and the data analysis; AL was in charge of the writing, the data collection and the data analysis; YW was in charge of the writing and the data analysis. All authors read and approved the final manuscript.

\section{Competing interests}

The authors declare that they have no competing interests.

The authors confirm that the content of the manuscript has not been published, or submitted for publication elsewhere. 


\section{Publisher's Note}

Springer Nature remains neutral with regard to jurisdictional claims in published maps and institutional affiliations.

\section{Received: 23 November 2018 Accepted: 2 April 2019}

Published online: 10 June 2019

\section{References}

Aiken, L. S., West, S. G., \& Reno, R. R. (1991). Multiple regression: Testing and interpreting interactions. Thousand Oaks: Sage.

Akgun, A., Lynn, G., \& Byrne, J. C. (2003). Organizational learning: A socio-cognitive framework. Human Relations, 56(7), 839868.

Altinay, L., Madanoglu, M., De Vita, G., Arasli, H., \& Ekinci, Y. (2016). The interface between organizational learning capability, entrepreneurial orientation, and SME growth. Journal of Small Business Management, 54(3), 871-891.

Ambos, T. C., Nell, P. C., \& Pedersen, T. (2013). Combining stocks and flows of knowledge: The effects of intra-functional and cross-functional complementarity. Global Strategy Journal, 3(4), 283-299.

Argyris, C., \& Schon, D. (1978). Organizational learning: A theory of action perspective. Reading, MA: Addison-Wesley.

Armstrong, J. S., \& Overton, T. S. (1977). Estimating nonresponse bias in mail surveys. Journal of Marketing Research, 14(3), $396-402$.

Atuahene-Gima, K., \& Murray, J. Y. (2007). Exploratory and exploitative learning in new product development: A social capital perspective on new technology ventures in China. Journal of International Marketing, 15(02), 1-29.

Bae, J., \& Lawler, J. J. (2000). Organizational and HRM strategies in Korea: Impact on firm performance in an emerging economy. Academy of Management Journal, 43(3), 502-517.

Bamiatzi, V., Bozos, K., Cavusgil, S. T., \& Hult, G. T. M. (2016). Revisiting the firm, industry, and country effects on profitability under recessionary and expansion periods: A multilevel analysis. Strategic Management Journal, 37(7), 1448-1471.

Baron, R. M., \& Kenny, D. A. (1986). The moderator-mediator variable distinction in social psychological research: Conceptual, strategic, and statistical considerations. Journal of Personality and Social Psychology, 51(6), 1173.

Becker, B. E., \& Huselid, M. A. (2006). Strategic human resources management: Where do we go from here? Journal of Management: Official Journal of the Southern Management Association, 32(6), 898-925.

Chadwick, K., Barnett, T., \& Dwyer, S. (2008). An empirical analysis of the entrepreneurial orientation scale. Journal of Applied Management and Entrepreneurship, 13(4), 64.

Chahal, H., Jyoti, J., \& Rani, A. (2016). The effect of perceived high-performance human resource practices on business performance: Role of organizational learning. Global Business Review, 17(3_suppl), 107S-132S.

Chan, C. M., Makino, S., \& Isobe, T. (2010). Does subnational region matter? Foreign affiliate performance in the United States and China. Strategic Management Journal, 31(11), 1226-1243.

Chen, S. Y., Uen, J. F., \& Chen, C. C. (2016). Implementing high performance HR practices in Asia: HR practice consistency, employee roles, and performance. Asia Pacific Journal of Management, 33(4), 937-958.

Cheng, D. J., \& Zhao, Y. (2011). A study on the mechanism of high performance work system on firm performance: The mediating role of organizational trust. Soft Science, 25(4), 96-99.

Chow, I. H. S., Teo, S. T., \& Chew, I. K. (2013). HRM systems and firm performance: The mediation role of strategic orientation. Asia Pacific Journal of Management, 30(1), 53-72.

Chuang, C. H., Jackson, S. E., \& Jiang, Y. (2016). Can knowledge-intensive teamwork be managed? Examining the roles of HRM systems, leadership, and tacit knowledge. Journal of Management, 42(2), 524-554.

Chung, H. F., Yang, Z., \& Huang, P. H. (2015). How does organizational learning matter in strategic business performance? The contingency role of guanxi networking. Journal of Business Research, 68(6), 1216-1224.

Clercq, D. D., Dimov, D., \& Thongpapanl, N. T. (2015). Structural and relational interdependence and entrepreneurial orientation in small and medium-sized enterprises: The mediating role of internal knowledge-sharing. International Small Business Journal, 33(5), 514-536.

Cohen, M. D., \& Sproull, L. S. (1996). Organizational learning. Thousand Oaks: Sage.

Covin, J. G., Green, K. M., \& Slevin, D. P. (2006). Strategic process effects on the entrepreneurial orientation-sales growth rate relationship. Entrepreneurship Theory and Practice, 30(1), 57-81.

Covin, J. G., \& Slevin, D. P. (1989). Strategic management of small firms in hostile and benign environments. Strategic Management Journal, 10(1), 75-87.

Dada, O., \& Fogg, H. (2016). Organizational learning, entrepreneurial orientation, and the role of university engagement in SMEs. International Small Business Journal, 34(1), 86-104.

Delaney, J. T., \& Huselid, M. A. (1996). The impact of human resource management practices on perceptions of organizational performance. Academy of Management Journal, 39(4), 949-969.

Dess, G. G., \& Lumpkin, G. T. (2005). The role of entrepreneurial orientation in stimulating effective corporate entrepreneurship. The Academy of Management Executive, 19(1), 147-156.

Dess, G. G., \& Robinson, R. B. (1984). Measuring organizational performance in the absence of objective measures: The case of the privately-held firm and conglomerate business unit. Strategic Management Journal, 5(3), 265-273.

Dixon, S. E. A., Meyer, K. E., \& Day, M. (2007). Exploitation and exploration learning and the development of organizational capability: A cross-case analysis of the Russian oil industry. Human Relations, 410(10), 617.

Dyer, L., \& Reeves, T. (1995). Human resource strategies and firm performance: What do we know and where do we need to go? International Journal of Human Resource Management, 6(3), 656-670.

Eisenhardt, K. M. (1989). Making fast strategic decisions in high-velocity environments. Academy of Management Journal, 32(3), 543-576.

El Akremi, A., Vandenberghe, C., \& Camerman, J. (2010). The role of justice and social exchange relationships in workplace deviance: Test of a mediated model. Human Relations, 63(11), 1687-1717.

Escribá-Esteve, A., Sánchez-Peinado, L., \& Sánchez-Peinado, E. (2008). Moderating influences on the firm's strategic orientation-performance relationship. International Small Business Journal, 26(4), 463-489.

Fernández-Mesa, A., \& Alegre, J. (2015). Entrepreneurial orientation and export intensity: Examining the interplay of organizational learning and innovation. International Business Review, 24(1), 148-156. 
Fiol, C. M., \& Lyles, M. A. (1985). Organizational learning. Academy of Management Review, 10(4), 803-813.

Floyd, S. W., \& Lane, P. J. (2000). Strategizing throughout the organization: Managing role conflict in strategic renewal. Academy of Management Review, 25(1), 154-177.

Floyd, S. W., \& Wooldridge, B. (1999). Knowledge creation and social networks in corporate entrepreneurship: The renewal of organizational capability. Entrepreneurship: Theory and Practice, 23(3), 123-123.

Greve, H. R. (2003). A behavioral theory of R\&D expenditures and innovations: Evidence from shipbuilding. Academy of Management Journal, 46(6), 685-702.

Guthrie, J. P. (2001). High-involvement work practices, turnover, and productivity: Evidence from New Zealand. Academy of Management Journal, 44(1), 180-190.

Hakala, H. (2011). Strategic orientations in management literature: Three approaches to understanding the interaction between market, technology, entrepreneurial and learning orientations. International Journal of Management Reviews, 13(2), 199-217.

Huergo, E., \& Jaumandreu, J. (2004). How does probability of innovation change with firm age? Small Business Economics, 22(3), 193-207.

Huselid, M. A. (1995). The impact of human resource management practices on turnover, productivity, and corporate financial performance. Academy of Management Journal, 38(3), 635-672.

Jerez-Gomez, P., Céspedes-Lorente, J., \& Valle-Cabrera, R. (2005). Organizational learning capability: A proposal of measurement. Journal of Business Research, 58(6), 715-725.

Kang, J., Rhee, M., \& Kang, K. H. (2010). Revisiting knowledge transfer: Effects of knowledge characteristics on organizational effort for knowledge transfer. Expert Systems with Applications, 37(12), 8155-8160.

Kreiser, P. M. (2011). Entrepreneurial orientation and organizational learning: The impact of network range and network closure. Entrepreneurship Theory and Practice, 35(5), 1025-1050.

Kreiser, P. M., Marino, L. D., \& Weaver, K. M. (2002). Assessing the psychometric properties of the entrepreneurial orientation scale: A multi-country analysis. Entrepreneurship Theory \& Practice, 26(4), 71.

Levitt, B., \& March, J. G. (2003). Organizational learning. Annual Review of Sociology, 14(14), 319-340.

Li, W., Li, P. P., Shu, C., \& Zhou, M. (2015). Ranking and mapping the contributions by overseas Chinese strategy scholars: A systematic and relevant analysis. Asia Pacific Journal of Management, 32(4), 1085-1108.

Li, Y. H., Huang, J. W., \& Tsai, M. T. (2009). Entrepreneurial orientation and firm performance: The role of knowledge creation process. Industrial Marketing Management, 38(4), 440-449.

Lipshitz, R., \& Popper, M. (2000). Organizational learning in a hospital. The Journal of Applied Behavioral Science, 36(3), 345-361.

Lumpkin, G. T., \& Dess, G. G. (1996). Clarifying the entrepreneurial orientation construct and linking it to performance. Academy of Management Review, 21(1), 135-172.

Lumpkin, G. T., \& Dess, G. G. (2001). Linking two dimensions of entrepreneurial orientation to firm performance: The moderating role of environment and industry life cycle. Journal of Business Venturing, 16(5), 429-451.

Lumpkin, G. T., \& Lichtenstein, B. B. (2005). The role of organizational learning in the opportunity-recognition process. Entrepreneurship Theory and Practice, 29(4), 451-472.

Mackinnon, D. P., Lockwood, C. M., \& Williams, J. (2004). Confidence limits for the indirect effect: Distribution of the product and resampling methods. Multivariate Behavioral Research, 39(1), 99-128.

Macky, K., \& Boxall, P. (2007). The relationship between 'high-performance work practices' and employee attitudes: An investigation of additive and interaction effects. The International Journal of Human Resource Management, 18(4), 537-567.

Messersmith, J. G., \& Wales, W. J. (2013). Entrepreneurial orientation and performance in young firms: The role of human resource management. International Small Business Journal, 31(2), 115-136.

Miller, D., \& Friesen, P. H. (1978). Archetypes of strategy formulation. Management Science, 24(9), 921-933.

Naldi, L., Nordqvist, M., Sjöberg, K., \& Wiklund, J. (2007). Entrepreneurial orientation, risk taking, and performance in family firms. Family Business Review, 20(1), 33-47.

Neter, J., Kutner, M. H., Nachtsheim, C. J., \& Wasserman, W. (1996). Applied Linear Statistical Models (Vol. 4, p. 318). Chicago: Irwin.

North, K., \& Kumta, G. (2018). Knowledge management: Value creation through organizational learning. Gewerbestrasse: Springer.

Noruzy, A., Dalfard, V. M., Azhdari, B., Nazari-Shirkouhi, S., \& Rezazadeh, A. (2013). Relations between transformational leadership, organizational learning, knowledge management, organizational innovation, and organizational performance: An empirical investigation of manufacturing firms. The International Journal of Advanced Manufacturing Technology, 64(5-8), 1073-1085.

Popova-Nowak, I. V., \& Cseh, M. (2015). The meaning of organizational learning: A meta-paradigm perspective. Human Resource Development Review, 14(3), 299-331.

Popper, M., \& Lipshitz, R. (2000). Organizational learning: Mechanisms, culture, and feasibility. Management learning. The Journal for Critical, Reflexive Scholarship on Organization and Learning, 31(2), 181-196.

Posthuma, R. A., Campion, M. C., Masimova, M., \& Campion, M. A. (2013). A high performance work practices taxonomy: Integrating the literature and directing future research. Journal of Management, 39(5), 1184-1220.

Preacher, K. J., \& Hayes, A. F. (2004). SPSS and SAS procedures for estimating indirect effects in simple mediation models. Behavior Research Methods, 36(4), 717-731.

Preacher, K. J., \& Hayes, A. F. (2008). Asymptotic and resampling strategies for assessing and comparing indirect effects in multiple mediator models. Behavior Research Methods, 40(3), 879-891.

Prieto, I. M.. \& Revilla, E. (2006). Assessing the impact of learning capability on business performance: Empirical evidence from Spain. Management Learning, 37(4), 499-522.

Rauch, A., Wiklund, J., Lumpkin, G. T., \& Frese, M. (2009). Entrepreneurial orientation and business performance: An assessment of past research and suggestions for the future. Entrepreneurship Theory and Practice, 33(3), 761-787.

Rosenbusch, N., Rauch, A., \& Bausch, A. (2013). The mediating role of entrepreneurial orientation in the task environmentperformance relationship a meta-analysis. Journal of Management: Official Journal of the Southern Management Association, 39(3), 633-659.

Ruekert, R. W., Walker, O. C., \& Roering, K. J. (1985). The organization of marketing activities: A contingency theory of structure and performance. Journal of Marketing, 49(1), 13-25. 
Sanzo, M. J., Santos, M. L., Garcia, N., \& Trespalacios, J. A. (2012). Trust as a moderator of the relationship between organizational learning and marketing capabilities: Evidence from Spanish SMEs. International Small Business Journal, 30(6), 700-726.

Schilling, M. A., \& Fang, C. (2014). When hubs forget, lie, and play favorites: Interpersonal network structure, information distortion, and organizational learning. Strategic Management Journal, 35(7), 974-994.

Shin, D., \& Konrad, A. M. (2017). Causality between HPWSs and organizational performance. Journal of Management, 43(4), 973-997.

Sobel, M. E. (1982). Asymptotic confidence intervals for indirect effects in structural equation models. Sociological Methodology, 13, 290-312.

Song, M., Droge, C., Hanvanich, S., \& Calantone, R. (2005). Marketing and technology resource complementarity: An analysis of their interaction effect in two environmental contexts. Strategic Management Journal, 26(3), 259-276.

Su, Z. X. (2010). High-performance human resource management system of Chinese enterprises in transitional period: An empirical study of localization. Nankai Business Review, 13(4), 99-108.

Tang, J., Tang, Z., Marino, L. D., Zhang, Y., \& Li, Q. (2008). Exploring an inverted U-shape relationship between entrepreneurial orientation and performance in Chinese ventures. Entrepreneurship Theory and Practice, 32(1), 219-239.

Tsao, C. W., Chen, S. J., Lin, C. S., \& Hyde, W. (2009). Founding-family ownership and firm performance: The role of HPWSs. Family Business Review, 22(4), 319-332.

Walter, A., Auer, M., \& Ritter, T. (2006). The impact of network capabilities and entrepreneurial orientation on university spinoff performance. Journal of Business Venturing, 21(4), 541-567.

Wang, C. L. (2008). Entrepreneurial orientation, learning orientation, and firm performance. Entrepreneurship: Theory and Practice, 32, 635-657.

Wei, L. Q., \& Lau, C. M. (2010). High performance work systems and performance: The role of adaptive capability. Human Relations, 63(10), 1487-1511.

Weinzimmer, L. G., \& Esken, C. A. (2017). Learning from mistakes: How mistake tolerance positively affects organizational learning and performance. The Journal of Applied Behavioral Science, 53(3), 322-348.

Wolff, J. A., Pett, T. L., \& Ring, J. K. (2015). Small firm growth as a function of both learning orientation and entrepreneurial orientation. International Journal of Entrepreneurial Behavior \& Research, 21(5), 709-730.

Wright, P. M., Dunford, B. B., \& Snell, S. A. (2001). Human resources and the resource based view of the firm. Journal of Management, 27(6), 701-721.

York, J. G., Vedula, S., \& Lenox, M. (2018). It's not easy building green: The impact of public policy, private actors, and regional logics on voluntary standards adoption. Academy of Management Journal, 61(4), 1492-1523.

Zahra, S. A., Jennings, D. F., \& Kuratko, D. F. (1999). The antecedents and consequences of firm-level entrepreneurship: The state of the field. Entrepreneurship: Theory and Practice, 24(2), 45.

\section{Submit your manuscript to a SpringerOpen ${ }^{0}$ journal and benefit from:}

- Convenient online submission

- Rigorous peer review

- Open access: articles freely available online

- High visibility within the field

- Retaining the copyright to your article

Submit your next manuscript at $\boldsymbol{s p r i n g e r o p e n . c o m ~}$ 